\title{
PRÁTICAS DE CONSUMO DOS FÃS DE BIG BROTHER BRASIL E A CULTURA DE MEMES
}

\section{Consumption practices of Big Brother Brazil fans and the culture of memes}

\section{Prácticas de consumo de los fans de Big Brother Brasil y la cultura de memes}

\author{
Luiza de Mello Stefano \\ Doutoranda da Universidade Federal Fluminense \\ luizamellost@gmail.com \\ Soraya Maria Ferreira Vieira \\ Professora da Universidade Federal de Juiz de Fora \\ sovferreira@gmail.com
}

\section{Resumo}

Este artigo analisa o modelo particular de consumo, produção e circulação de conteúdo televisivo das comunidades de fãs no Twitter do programa de reality show Big Brother Brasil. As discussões refletem pesquisas feitas entre a $16^{a}$ e $20^{a}$ edição, com foco no BBB 18 , em que foi realizada uma imersão na comunidade de fãs com inspiração etnográfica. Identificamos de que maneira os usuários participam e se relacionam com os conteúdos e complexificam a experiência do consumo, com destaque para a produção de memes como forma de linguagem e engajamento. Os resultados nos fazem crer que a cultura de memes está intimamente relacionada à reconfiguração do consumo televisivo.

Palavras-chave: BBB. Fãs. Memes.

\begin{abstract}
This article analyzes the particular model of consumption, production and circulation of television content by fan communities on Twitter of the reality show Big Brother Brasil. The discussions reflect research carried out between the 16th to the 20th edition, with a focus on BBB 18, in which an immersion in the fan community was carried out with ethnographic inspiration. We identified how users participate and relate to the content and complex the experience of consumption, with emphasis on the production of memes as a form of language and engagement. The results make us believe that the culture of memes is closely related to the reconfiguration of television consumption.
\end{abstract}

Key words: BBB. Fans. Memes.

\section{Resumen}

Este artículo analiza el modelo particular de consumo, producción y circulación de contenido televisivo por comunidades de fanáticos en Twitter del reality show Big Brother Brasil. Las discusiones reflejan la realizada entre la 16 y la 20 edición, con un enfoque en BBB 18, en la que se llevó a cabo una inmersión en la comunidad de fanáticos con inspiración etnográfica. 
Identificamos cómo los usuarios participan y se relacionan con el contenido y complejan la experiencia de consumo, con énfasis en la producción de memes como una forma de lenguaje y compromiso. Los resultados nos hacen creer que la cultura meme está estrechamente relacionada con la reconfiguración del consumo de televisión.

Palabras clave: BBB. Aficionados. Memes.

\section{INTRODUÇÃO}

O paradigma comunicacional contemporâneo diante das possibilidades inauguradas pela conectividade, tem alterado as formas de distribuir e circular conteúdo e, consequentemente, o modo de assistir e produzir televisão. Diversos fenômenos, sejam eles tradicionais ou emergentes, estão no cerne da reconfiguração da experiência televisiva: o surgimento da internet e das redes sociais, a convergência midiática, o desenvolvimento da cultura participativa e da subcultura fã. Embora não se configuram como fenômenos recentes, todos se amplificaram e ganharam indiscutível visibilidade com o surgimento das plataformas digitais. Mais recentemente, a cultura de memes se inseriu nesse grupamento e engendrou modos atualizados de consumir televisão e interagir a partir dela. Dentro desse quadro geral de reordenamentos, os memes ganham novos significados e funções na medida em que adentram cada vez mais a cultura massiva, em especial a televisão.

A web possibilitou que os usuários mais engajados formassem comunidades e vínculos sociais em um ambiente onde pudessem se comunicar, expandir seus conteúdos e ampliar o escopo de atividades criativas. A conectividade presenteou os fãs com um espaço não somente de encontro, mas, sobretudo, de construção e compartilhamento de formas de produção coletivas e colaborativas.

O modelo particular de consumo dos fãs na contemporaneidade se destaca sobretudo em programas de entretenimento, como telenovelas, reality shows e séries ficcionais. Para Machado (2011, p. 89), o reality show "exige um espectador inquieto e participativo, que sai da frente do televisor para buscar outras fontes de informação". Na mesma perspectiva, Mateus (2012) defende que uma das chaves para o sucesso do gênero é a experiência coletiva ser praticamente obrigatória. Campanella (2008) realizou uma extensa pesquisa etnográfica dos fãs do Big Brother Brasil em sua $8^{\text {a }}$ edição e argumenta que os reality shows tornaram-se um formato adaptável para várias plataformas de difusão ao explorar o potencial da convergência midiática. A atração se constitui como um movimento social em rede que induz naturalmente o debate, a conversa, a crítica, o diálogo do espectador com a TV e as demais plataformas. 
Dessa forma, as possibilidades de identificar o modelo particular de consumo, produção e circulação de um público que sempre se mostrou intensamente participativo e engajado, resultou na escolha do Big Brother Brasil (BBB) e de seus fãs como objetos empíricos. A atração, que veiculou sua primeira temporada em 2002, foi criado concomitantemente com o surgimento das novas tecnologias e vem apresentando, a cada edição, novas ações e estratégias para se adequar ao mercado atual (STEFANO; VIEIRA, 2017). As características do gênero e as particularidades do formato, entre eles a hibridez, o caráter participativo e a compatibilidade com a convergência midiática, além da amplitude do fenômeno à nível nacional, destacam o potencial significativo do programa e de seus fãs como objetos de estudo. Vale destacar que recentemente, no contexto da pandemia, o programa ganhou ainda mais notoriedade no cenário televisivo brasileiro, sendo um dos programas de maior audiência e participação do Brasil ${ }^{1}$.

Ainda há uma relação significativa entre os fãs e a indústria televisiva que precisa ser estudada e compreendida para que novas estratégias apropriadas ao atual cenário comunicacional possam ser criadas. Nesse contexto, buscou-se entender quais são as práticas de consumo, produção e circulação que surgem no modelo televisivo contemporâneo quando a figura do fã se torna protagonista. Investigamos, através da conexão entre TV e web, de que forma os usuários circulam e ressignificam as informações geradas pelo Big Brother Brasil, como eles respondem as ações de engajamento e participação e, principalmente, quais tipos de conteúdo se repetem na participação dos fãs.

Os dados apresentados neste trabalho resultam de uma extensa pesquisa que teve início na $16^{\mathrm{a}}$ edição do programa (STEFANO, 2016) e se desdobra até a $20^{\mathrm{a}}$ edição, com foco nas transformações pelas quais o produto passou ao longo dos últimos anos no que diz respeito à conectividade entre TV e internet, produto e fãs. $\mathrm{Na} 18^{\mathrm{a}}$ temporada, durante minha pesquisa de mestrado, realizei uma observação imersiva com inspiração etnográfica em que foi possível identificar a composição da dinâmica comunicacional do programa ao analisar a estrutura e práticas culturais da comunidade de fãs no Twitter - incluindo hábitos, comportamentos, práticas, linguagens, características, formas de sociabilidade; assim como suas repercussões e modos de interferência no programa exibido na TV aberta (STEFANO, 2019).

\footnotetext{
1 Disponível em: <https://f5.folha.uol.com.br/televisao/bbb21/2021/03/bbb-21-supera-edicoes-anteriores-comalcance-diario-de-399-milhoes-de-pessoas.shtml>. Acesso em 29 abr. 2021.
} 
Neste artigo, vou me debruçar especificamente nesse modelo de consumo, produção e circulação dos fãs do programa no Twitter. O objetivo é analisar os principais pontos extraídos da pesquisa de campo feita em 2018 e se os mesmos se mantiveram na $20^{\mathrm{a}}$ edição do programa, exibida entre 21 de janeiro de 2020 a 27 de abril de 2020.

Levando em consideração os objetivos e as particularidades dos objetos empíricos, a pesquisa realizada em 2018 foi dividida em três etapas correlacionadas: monitoramento através da observação não participativa ${ }^{2}$, coleta de dados e análise. Todas as fases foram conduzidas simultaneamente entre o dia primeiro de janeiro de 2018 a 20 de abril de 2018, período que inclui o início da divulgação da nova temporada nas redes sociais e o último episódio exibido na TV. No processo de monitoramento, optei pela observação imersiva com inspiração etnográfica como metodologia. O método abrange a cultura, a observação e pesquisa de campo. Neste estudo, ela foi realizada nas comunidades virtuais no Twitter que, além de ser popularmente a principal plataforma para uso síncrono ao consumo televisivo (PROUXL; SHEPATIN, 2012), no caso do BBB, apresenta a maior concentração de fãs participativos.

Para Amaral, Natal e Viana (2008, p.35) "a etnografia virtual leva em conta as práticas de consumo midiático, os processos de sociabilidade e os fenômenos comunicacionais que envolvem as representações do homem dentro de comunidades virtuais". Segundo Campanella (2012), a prática etnográfica surge a partir da combinação de técnicas anteriormente adotadas nos estudos de recepção e vai além dos estudos tradicionais de audiência que abordam unicamente a recepção televisiva. "[...] os estudos de recepção usualmente se concentram nas análises (centradas na mídia) entre texto e receptor, enquanto que o estudo da etnografia midiática estaria focado na interação social (e com o mundo material) de certos grupos de pessoas" (TUFTE, 2000, p. 27 apud CAMPANELLA, 2012, p. 39). As novas plataformas e a ubiquidade do consumo televisivo modificam significativamente as formas de produção, recepção e circulação de conteúdo e, por isso, “[...] os estudos etnográficos das mídias enfrentam agora o desafio de ultrapassar as fronteiras do ambiente doméstico para chegar aos novos espaços onde esses textos estão sendo significados e discutidos" (CAMPANELLA, 2012, p. 44).

Durante os quatro meses de observação, acompanhei diariamente as postagens realizadas no Twitter com a hashtag \#RedeBBB (oficial do programa) e \#BBB18 (a mais

\footnotetext{
${ }^{2}$ A observação não participativa, também conhecida como não-obstrutiva, restringe-se ao acompanhamento das postagens e discussões dentro da comunidade sem qualquer tipo de participação, ou seja, sem produzir conteúdo ou interagir com os fãs.
} 
utilizada pelos fãs). A metodologia incluiu, além da incorporação de técnicas complementares de coleta e arquivamento de $\operatorname{dados}^{3}$, o registo a cada três dias dos principais acontecimentos e dinâmicas entre os fãs e o programa observados no período. Essa periodicidade foi necessária devido, entre outros motivos, à grande quantidade de dados. Seguindo essa rotina, foi possível construir um diário de campo com mais de noventa páginas de apontamentos, anotações e descrição; mais de 300 tweets arquivados e mais de 590 minutos de gravação de tela da interface do Tweetdeck com os tweets publicados pelos fãs em sete dias específicos. Tal material empírico foi minimizado e resultou na análise que será explanada neste artigo.

\section{FANDOM BBB: PARTICULARIDADES NO CONSUMO TELEVISIVO}

O fenômeno da social $T V$ diz respeito ao ato de compartilhar, debater e divulgar a programação televisiva de maneira síncrona nas redes sociais, principalmente no Twitter. Prouxl e Shepatin (2012, p. 9) definem o fenômeno como a "convergência entre a televisão e as mídias sociais”. A reconfiguração da experiência televisiva se potencializa a partir dessa conexão que faz com que falar, debater e comentar sobre TV se tornem tão importantes e interessantes quanto assisti-la.

No atual modelo da conectividade, a forma com que os conteúdos circulam entre meios tradicionais e emergentes também muda. Jenkins et al. (2014) defendem a máxima "o que não se propaga está morto". Há uma cultura do compartilhamento em que o conceito de propagabilidade se destaca. Segundo os autores, a propagabilidade se refere ao potencial do público de compartilhar conteúdo por interesses próprios e aos recursos técnicos que tornam mais fácil a circulação de algum tipo de conteúdo em comparação com outros (JENKINS et al., 2014).

Nesse contexto, a atividade fã não se esgota. Para Jenkins (2015, p. 23) “a cultura fã é um fenômeno complexo, multidimensional, que atrai diversas modalidades de participação e

\footnotetext{
${ }^{3}$ Devido à incapacidade de acesso a todas as informações e tweets do programa, utilizamos ferramentas de coleta e arquivamento de dados para nos resguardar quanto à efetividade da pesquisa. A primeira técnica foi o arquivamento semanal de dados quantitativos acerca da circulação no Twitter a partir das hashtags \#RedeBBB e \#BBB18 através da plataforma Opsocial. A segunda metodologia criada para a coleta de dados tinha como objetivo arquivar um material empírico a partir de um corpus reduzido que pudesse ser acessado e analisado em um período posterior à exibição do programa. Com o auxílio das plataformas gratuitas TweetDeck e o Snagit, gravamos na íntegra todos os tweets postados com as hashtags selecionadas durante sete dias não consecutivos no período de trinta minutos antes do programa começar, durante a exibição do mesmo e trinta minutos após o seu término. Porém, ao final do período empírico, percebemos que a rotina diária de observação crítica e acompanhamento dos comentários no Twitter em diferentes momentos ao longo do dia se mostrou mais eficaz e possibilitou responder as questões propostas. Para saber mais sobre a metodologia de pesquisa e o material empírico, acessar (STEFANO, 2019).
} 
níveis de engajamento”. Os fãs possuem um modelo particular de consumo e produção com características similares à de uma comunidade social, que inclui hierarquias, regras, hábitos, rituais, conflitos, agregações e rupturas.

O termo "comunidade virtual" foi cunhado por Rheingold (2000, p. 20, tradução nossa) na década de 90 e, segundo o autor, são “[...] agregados sociais que surgem da Internet, quando uma quantidade suficiente de pessoas leva adiante essas discussões públicas durante um tempo suficiente [...] para formar redes de relações pessoais no ciberespaço". Ao falar em comunidades particularmente de fãs, Jenkins adota o termo fandom que, segundo o autor, começou a ganhar forma com o acesso facilitado às fitas de vídeo e "[...] transforma a experiência do consumo televisivo na produção de novos textos, ou ainda mais, de uma nova cultura e uma nova comunidade" (JENKINS, 2015, p. 63). Em compreensão mais recente, Jenkins, Ford e Green (2014, p. 210) definem fandom como "[...] um tipo de coletividade (no qual eles agem como comunidades em vez de indivíduos) e conectividade (no qual seu poder é amplificado por seu acesso às comunicações ligadas em rede) cuja presença está sendo sentida na cultura contemporânea".

Os fãs têm predisposição à mobilização e compartilhamento de conteúdo e se caracterizam pelo envolvimento com os produtos que acompanham. O público televisivo contemporâneo não só consome, mas cria conteúdo, muda as possibilidades de participação e exerce grande influência nos meios de comunicação. Ronsini et al. (2015, p. 224) denominou de ativismo fã o fenômeno que consiste na atuação articulada dos membros de determinado fandom "em torno de uma ou mais causas em comum". Essa prática interacional se potencializa nas redes sociais e tem o intuito de fazer prevalecer as preferências, valores e opiniões dos fãs.

A circulação de conteúdo feita pelos usuários com a hashtag \#BBB18 e \#RedeBBB durante os mais de cem dias de monitoramento foi intensa. Ao longo do período empírico foi árduo, por vezes, acompanhar todos os tweets postados devido ao grande volume de conteúdo que foi sendo criado e propagado, substituindo os anteriores rapidamente. Grande parte deles refere-se ao que está acontecendo dentro do reality em tempo real através do consumo do payper-view, assim como das notícias divulgadas pelo próprio programa em suas redes sociais oficiais.

Seguindo essa linha, a primeira prática de consumo observada foi o hábito de narrar a rotina dos participantes. Esta prática faz com que, mesmo aqueles que não possuem o payper-view, conseguissem facilmente acompanhar os últimos acontecimentos do cotidiano da 
casa do Big Brother Brasil através das publicações feitas com as hashtags oficiais. Percebe-se, naquelas pessoas que têm acesso às câmeras da casa, um sentimento de obrigação social de compartilhar os fatos com os que não usufruem do serviço.

Ao chegar perto do horário de exibição do programa na TV, as mensagens apresentam um sentimento de expectativa para o evento do dia - seja a prova do líder ou anjo, formação de paredão, jogo da discórdia, eliminação ou festas. No momento em que o programa começa, torna-se de fato impraticável acompanhar, junto com o fandom, todos os tweets postados. Conseguimos perceber, portanto, a prática de social $T V$ fortemente instaurada no modelo de consumo desses fãs.

Durante a imersão na comunidade de fãs do BBB foi possível constatar que o maior volume de tweets acontece durante a exibição do programa, de modo mais concreto no intervalo comercial, seguido do período após o término da transmissão. Essa particularidade também foi observada na $16^{\mathrm{a}}$ edição do programa, em que o volume de conversas criadas no Twitter obteve seu pico durante e logo após a transmissão televisiva (STEFANO, 2016) e se confirmou mais uma vez na $20^{\mathrm{a}}$ edição. Na perspectiva qualitativa, nesse momento, destacaram-se os conteúdos com mensagens mais curtas, em sua maioria apenas narrando ou opinando objetivamente sobre o que está sendo exibido naquele instante na TV. Os fãs estão mais atentos ao programa na Rede Globo e empenhados em compartilhar seus pontos de vista. Após o término do programa, a permanência do intenso volume de tweets revela a preferência dos fãs do Big Brother Brasil em comentar detalhadamente o episódio que foi ao ar, momento em que novos conteúdos rapidamente são criados e disseminados nas redes.

Outra prática identificada no modo particular de consumo dos membros do fandom foi a utilização das próprias ferramentas do Twitter para realizar votações internas com o objetivo de mensurar a popularidade ou rejeição de determinado participante ou grupo. Com a opção de favoritar ou retweetar a postagem de acordo com o significado de cada ação, essa prática está intimamente ligada ao conceito de propagabilidade, uma vez que apresenta uma dinâmica que potencializa a circulação e distribuição do conteúdo.

A intensa atividade de envolvimento dos fãs do BBB foi materializada na exposição dos Trending Topics ${ }^{4}$ que, durante as temporadas, rotineiramente exibiam os assuntos mais comentados pelos fãs sobre a atração. O que chamou atenção, porém, foi o fato de alguns termos terem ganhado destaque de forma totalmente espontânea. Isto é, não representavam campanhas coletivas em que o objetivo principal era justamente a inserção da hashtag na lista

\footnotetext{
${ }^{4}$ Lista em tempo real das palavras mais postadas no Twitter.
} 
dos assuntos mais comentados do momento no Twitter, mas frases e expressões expostas durante o confinamento ou a transmissão ao vivo. Termos como "PAULA IMUNE AO VETO”, "INDICOU A PAULA", "ELE SÓ TEM DERROTAS”, "NÃO QUERO FALAR COM NINGUEM", "QUASE 95\%” e diversos outros equivalentes revelam a expansão do fenômeno Big Brother Brasil, o grande volume de usuários envolvidos com a atração e que deseja não só participar e comentar, mas sobretudo narrar os acontecimentos do reality.

Outro comportamento integralmente observado ao longo da imersão foi a disputa entre fandoms e as articulações para conseguir defender seu participante favorito no jogo. A grande final do BBB 18 disputada por Gleici (campeã), Kaysar (vice-campeão) e Família Lima (terceiro lugar) reflete as maiores comunidades construídas no Twitter na temporada de acordo com o monitoramento realizado. O envolvimento entre os fãs e seus " $f a v s$ " - como eles denominavam o participante pelo qual estavam torcendo - originou apelidos que os próprios interatores deram para si, como "formigas", "caracos" e "pimentas" representando respectivamente os fãs de Gleici, Kaysar e Ana Clara. É possível especular, considerando as implicações desse comportamento, a busca por reconhecimento e construção de identidade e sentidos a partir do perfil dos participantes selecionados para compor o programa.

As eliminações, por outro lado, se mostraram uma disputa muito mais complexa envolvendo as comunidades de fãs do que apenas votar para que seu participante favorito continuasse na disputa. A união entre os fandoms e a dinâmica própria dos membros evidenciaram a elaboração de estratégias e ações coletivas extremamente efetivas para aumentar a força dos fandoms e, consequentemente, as chances de eliminar o adversário em comum. Em todos os paredões semanais houve intensa discussão no microblogging com postagens dos mais variados formatos que elencavam motivos e argumentos em prol de determinado participante. Após intenso debate, o fandom votava em conjunto e dificilmente divergia nos votos. Os responsáveis por manter a conta dos participantes ativa nas redes tinham um papel fundamental dentro da comunidade, uma vez que protagonizavam a função de líder do fandom. Esse modo de consumo coletivo evidencia uma característica fortemente presente nas comunidades: sua semelhança aos grupos sociais, em que há hierarquias, disputa de poder, discussões e também um espaço para que os usuários exponham seus argumentos e escolham como se posicionar a cada semana.

É bastante representativo o grau de complexidade e organização atingido por essas fãs, que frequentemente fazem uso de várias plataformas e multiplicidade de formatos para difundir seus conteúdos e ampliar a rede de interações em torno do fandom. Os usuários 
conseguem identificar e mapear os diferentes tipos de público que o reality possui e criar estratégias específicas para cada um deles com base em uma lógica ecossistêmica na qual o programa se insere. Em determinado momento da temporada, por exemplo, fãs da participante Gleici criaram conteúdo a serem propagados especificamente no Facebook para aumentar o alcance da candidata na rede social.

Também no âmbito da coletividade, outra prática observada foi a criação de campanhas para influenciar decisões do programa, ação que se enquadra no conceito de ativismo fã. Como vimos, o fenômeno refere-se a prática colaborativa de usuários pertencentes a uma mesma comunidade com propósitos em comum. Observamos que os fãs do Big Brother Brasil nutrem um sentimento de posse e controle que os fazem acreditar no direito de criticar e reivindicar as decisões da produção que vão contra seus interesses e expectativas, exigindo mudanças sempre que necessário. Durante o período empírico foi constatado diversas campanhas coletivas de ativismo fã que impactaram no programa exibido na TV. O \#ForaFamíliaLima foi o primeiro caso do fenômeno e ocasionou em uma conversa particular do apresentador com os participantes envolvidos devido à grande repercussão nas redes sociais. A interferência da produção no confinamento surpreendeu os fãs e dividiu opiniões no fandom. Com o passar da temporada, os usuários começaram a perceber a maior abertura do programa à respeito de suas ações e aproveitá-la, reivindicando todo e qualquer ponto que a comunidade achasse que prejudicava o andamento do jogo ou o seu participante favorito.

Três dinâmicas criadas pelo programa foram canceladas ou alteradas a partir do ativismo fã: o "testamento do eliminado", o paredão "vai e volta" e uma edição do "jogo da discórdia". Em todos os casos o apresentador, Tiago Leifert, ao anunciar a mudança, fez referência ao usuário-fã como o gerador das alterações, aquele que alertou o programa sobre brechas ou contradições em sua dinâmica. Por fim, o erro na prova do líder que aconteceu no dia 15 de fevereiro de 2018 enfatiza a instantaneidade e o comportamento crítico e atento no modo de consumo e circulação dos fãs. A campanha iniciada pelos usuários logo após o término da prova ocasionou no anúncio, quase igualmente imediato, do erro e alteração na liderança. O programa interrompeu a programa da Rede Globo para comunicar aos participantes sobre o equívoco e eleger o novo líder. É possível dizer que é a primeira vez que um comunicado de erro em provas tenha acontecido de forma tão imediata. 


\section{CONTINUIDADES NAS PRÁTICAS DE CONSUMO}

Todas as práticas destacadas até aqui, percebidas durante imersão na comunidade de fãs da $18^{\mathrm{a}}$ edição do programa, se mantiveram e, mais ainda, se potencializam na $20^{\mathrm{a}}$ temporada. A inédita mistura de famosos da internet (influenciadores, cantores, atores e atletas) com anônimos para compor o elenco de participantes aumentou consideravelmente o alcance do programa nas redes e na TV. Reflexo disso foi o recorde mundial de votação em um programa de televisão no $10^{\circ}$ paredão entre Manu, Mari e Prior com 1,5 bilhão de votos.

A partir de uma pesquisa exploratória entre janeiro a abril de 2020, foi possível perceber que os fãs continuam utilizando o Twitter para comentar, concomitantemente à exibição na TV, sobre as últimas novidades do jogo. Quando o programa não está no ar, o hábito de narrar os acontecimentos da rotina dos participantes durante o dia e madrugada se reafirma. Há diversos vídeos de cenas específicas sendo propagadas diariamente nas redes. Cada um deles gera um imenso debate que, muitas vezes, excede o ambiente do programa e molda a opinião do público nos momentos de votação. A complexidade envolvendo os fandoms a cada semana que percebemos nos estudos anteriores, na $20^{\mathrm{a}}$ temporada ganha uma relevante proporção. Pautas importantes como assédio, machismo, racismo e feminismo geraram intensa discussão e determinaram, muitas vezes, os eliminados da semana. Esse intenso debate gerou cerca de 271,4 milhões de tweets, cerca de dez vezes a mais que da edição anterior ${ }^{5}$. A final, disputada em 27 de abril de 2020, foi o momento do programa com a maior quantidade de comentários na rede social.

$\mathrm{O}$ reality diariamente apareceu nos assuntos mais comentados no Twitter, seja de maneira espontânea expondo acontecimentos do jogo, seja de maneira deliberada com campanhas de apoio ou que exigiam posicionamento do programa em certas ocasiões, igualmente como ocorreu durante a $18^{\mathrm{a}}$ edição. A hashtag \#PetrixExpulso, por exemplo, foi a primeira grande campanha feita pelos fãs, enquanto \#ProvaManipulada e "Rafa apertou primeiro" demonstram a insatisfação dos fãs acerca da disputa pela liderança. Os termos como "PRIOR SAIU” e "DANIEL NO PAREDÃO", surgem espontaneamente e confirmam a prática de narrar os acontecimentos do jogo e do convívio dos participantes.

Da $18^{\mathrm{a}}$ para a $20^{\mathrm{a}}$ edição do Big Brother Brasil percebemos uma intensificação do fenômeno do ativismo fã que pode estar relacionada com a forma que o programa apresenta

\footnotetext{
${ }^{5}$ Conforme reportagem disponível em: < https://kogut.oglobo.globo.com/noticias-da-tv/noticia/2020/04/bbb-20teve-dez-vezes-mais-mencoes-no-twitter-que-o-anterior-veja-ranking-dos-participantes.html>. Acesso em: 05 maio 2020 .
} 
estratégias e dinâmicas mais participativas. O comportamento tanto por parte do fandom de exigir determinado posicionamento quanto do programa de acatar ou ao menos comentar as reivindicações dos usuários, se tornou rotineira. Toda e qualquer campanha de reivindicação iniciada pelos usuários era obrigatoriamente comentada pelo apresentador. Percebe-se que a intensidade no modo de reivindicar e protestar dos fãs aumenta na mesma proporção em que o programa se mostra mais aberto ao engajamento do público e oferece liberdade para os usuários opinarem, se tornando em muitos casos apenas um mediador dos assuntos que os fãs propagavam. O que pode gerar, em alguns momentos, abordagens negativas. A $20^{a}$ edição foi protagonizada pela cultura de cancelamento que se intensificou na $21^{\mathrm{a}}$ edição. Ela consiste na ruptura do fã com a comunidade na qual ele está alinhado ou, em casos extremos, no pedido de expulsão do participante. $\mathrm{O}$ fato é que todos eles, em algum momento do jogo, foram cancelados pelos usuários. Nutridos de um sentimento de posse e controle, frequentemente foram feitas campanhas com hashtags e menções aos produtores, patrocinadores e ao apresentador do programa exigindo posicionamentos.

A complexidade envolvendo a torcida dos fandoms que percebemos de forma enfática nas edições anteriores, ganhou uma relevante proporção na $20^{\mathrm{a}}$ temporada com a inserção de pessoas públicas se aliando às comunidades de fãs. Os mutirões de votos ganharam novas dinâmicas e estratégias. Além da divisão entre fãs ser influenciada sobremaneira pelo discurso que o participante tinha na casa, ela ganhou ainda mais destaque ao polarizar grupos políticos e sociais, tais quais atletas versus atores e cantores. Dentro das comunidades de fãs, para decidir quem seria o eliminado da semana, os usuários tinham que elencar, por vezes, qual participante teria cometido o pior erro e criavam uma espécie de ordem de eliminação. Se por um lado os debates nas redes sociais alavancaram o engajamento do BBB, o programa, por sua vez, foi o grande motivador dessa grande rede de opiniões, principalmente com a escolha estratégica de pessoas públicas e participantes com valores e personalidades divergentes.

\section{MEMES COMO FORMA DE LINGUAGEM E EXPRESSÃO}

A produção e circulação de memes é, indiscutivelmente, a atividade de maior destaque na comunidade de fãs no Big Brother Brasil. Pela capacidade de serem remixados inúmeras vezes para transmitirem uma opinião ou sentimento, os memes apresentam um caráter complexo ao aglutinar diversas referências, recursos e contextos em um só conteúdo que nos ajudam a entender com mais precisão o modo particular de consumo desse público. Segundo 
Jenkins $(2015$, p. 55), “[...] os fãs têm prazer de construir conexões intertextuais entre uma ampla gama de textos. [...] sua participação vai além do interesse por um único texto e engloba muitos outros". Os fãs possuem vasto repertório cultural e audiovisual que está relacionado com a memória afetiva e social de produtos midiáticos já consumidos. Dessa forma, eles introduzem novos sentidos em um processo constante de ressignificação de conteúdos que origina a produção de memes.

O termo surgiu em um contexto totalmente diferente do que vemos nos dias atuais. Ele apareceu pela primeira vez nos estudos da biologia relacionado à memória dos organismos e significava unidades contagiosas ou herdadas de informação cultural. Cunhado por Dawkins (1976), o termo memes era fundamentado na replicação de ideias, conhecimento e outras informações culturais através da imitação e transferência. Para o autor, o meme, na dimensão genética, representa um gene da cultura carregado de uma mensagem capaz de ser replicada e transmitida de uma pessoa para outra.

As primeiras pesquisas sobre o fenômeno focam em reflexões e discussões sobre a temática sem base empírica (BLACKMORE, 2000). Shifman (2013) traz a discussão para o cenário da cultura digital e inaugura uma $2^{\mathrm{a}}$ geração de pesquisadores ao ressignificar a definição dada por Dawkins e demais memeticistas da $1^{\text {a }}$ geração. Os estudos subsequentes consideram o meme como um gênero comunicacional no contexto da cultura participativa (WIGGINS; BOWERS, 2014) e associam o aspecto viral desses artefatos com o atual modelo da mídia propagável/espalhável (JENKINS et. al., 2014). Para o Chagas et al. (2017, p. 179), o meme é "um produto cultural que depende de um repertório cultural extraído de relações sociais, memórias, referências históricas, geográficas, econômicas e de aspectos conjunturais específicos". Dessa forma, eles introduzem novos sentidos em um processo constante de ressignificação de conteúdos.

Trabalhado de modo muitas vezes interdisciplinar, inúmeras categorias, classificações e modelos de taxonomia foram desenvolvidas. A maioria se limita a refletir o fenômeno ainda com base nas primeiras observações de Dawkins (1976) a respeito do sucesso dos memes e dos níveis de fidelidade, longevidade e fecundidade. De maneira resumida, a fidelidade se refere à qualidade do meme que permite que ele seja prontamente copiado e passado de mente em mente relativamente intacto; a fecundidade se refere à taxa na qual uma ideia ou padrão é copiado e espalhado. A terceira característica-chave de um meme bem-sucedido, a longevidade, diz respeito à vida útil de um meme, ou seja, o quanto ele sobrevive (KNOBEL; LANKSHEAR; 2007; DAWKINS, 1976). No cenário brasileiro, a pesquisa de Raquel 
Recuero (2007) traz a discussão para o contexto digital e propõe uma quarta chave de análise além das já discutidas por Dawkins: o alcance. Segunda a autora, o alcance refere-se ao potencial do meme de percorrer diferentes grupos de usuários. Eles podem ser globais ou locais e dizem respeito aos laços e conexões construídas.

Ao pegarmos como ponto de partida os três eixos apresentados por Dawkins, Knobel e Lankshear (2007) destacam outras peculiaridades que repousam nos memes considerados bem-sucedidos: a presença da intertextualidade, do humor ou ironia, da justaposição e natureza colaborativa. Em diálogo com as categorizações apresentadas, acrescentamos a metalinguagem como outra particularidade fortemente presente nos memes circulados na rede. Enquanto a intertextualidade diz respeito à referência cruzada de uma série de eventos, produtos midiáticos, práticas culturais e populares que convergem em um só conteúdo (KNOBEL; LANKSHEAR, 2007), a metalinguagem, por sua vez, refere-se ao diálogo de um meme com outro já existente. Para Chalhub (2005), no contexto da literatura, "a intertextualidade é uma forma de metalinguagem, onde se toma como referência uma linguagem anterior" (CHALHUB, 2005, p.52).

Dentro das comunidades de fãs, os memes apresentam um caráter complexo ao aglutinar diversas referências, recursos e contextos em um só conteúdo que nos ajudam a entender com mais precisão o modo particular de consumo da cultura fã. Os memes traduzem como os usuários consomem o programa ao longo da temporada. No quesito da intertextualidade, foi possível perceber dois modelos durante a pesquisa empírica: memes que eram construídos com referências externas ao programa e memes produzidos com material do próprio reality. No primeiro caso, personagens já consolidados na web e na cultura de memes, como a blogueira e youtuber Tulla Luana e da cantora Gretchen - intitulada a rainha dos memes, são apropriados pelos usuários na produção de conteúdo.

Alguns memes se sobressaíram durante a $18^{\mathrm{a}}$ edição. Um deles foi criado pelos fãs com base no enredo da novela das nove em exibição na época, "Do outro lado do Paraíso". A conexão entre os dois produtos foi construída a partir da imagem da cena do retorno da personagem principal Clara à trama. A remixagem consistia na troca do rosto da personagem pelo rosto dos participantes do BBB. A frase "vocês não imaginam o prazer que é estar de volta", dita pela atriz na novela, foi apropriada pelos fãs e inserida em contexto em diversos momentos, sendo empregada repetidamente quando o participante no qual eles estavam torcendo retornava do paredão. O meme transmitia, portanto, um sentimento coletivo da comunidade virtual provocado pelos acontecimentos do jogo e foi replicado de forma 
significativa. O meme ganhou destaque também na TV e foi apropriado pelo programa para elaboração de estratégias, dinâmicas e quadros especiais.

Ao contrário desse meme que referenciava um produto da própria emissora, os usuários também faziam conexões com materiais externos à Rede Globo e ao reality show. Um deles foi o meme que se apropriava da imagem de divulgação da sexta temporada da série norte-americana Pretty Little Liars (2010-2017), exibida em 2015. A imagem foi remixada pelos fãs: o rosto das atrizes foi trocado pelo dos participantes do Big Brother Brasil, enquanto em cima do caixão foi colocado o rosto daqueles que os fãs queriam ver fora do programa (Figura 1). Analisando semioticamente, o caixão constituía um índice: o competidor derrotado ou aquele que os fãs queriam que fosse eliminado. Uma outra possibilidade era a inserção do símbolo do Twitter junto aos sujeitos que carregavam o caixão, simbolizando a força que a comunidade de fãs no microblogging possuía no jogo.

A narrativa criada pelos fãs na $18^{\mathrm{a}}$ edição se repetiu na $20^{\mathrm{a}}$ temporada (Figura 1). Os usuários, através de seus repertórios midiáticos e munidos da memória afetiva acerca do programa, utilizaram o mesmo meme em um contexto semelhante sem que houvesse dificuldade no entendimento devido à questão temporal. Dois anos depois da criação do meme, o mesmo foi colocado em circulação novamente, confirmando a prática fã e potencializando sua relevância no modelo de consumo do fandom. Este caso evidencia a característica que destacamos referente ao vasto repertório cultural dos fãs.

Figura 1 - Meme criado pelos fãs em que faz referência a série "Pretty Little Liars" na $18^{a}$ e $20^{a}$ edição.
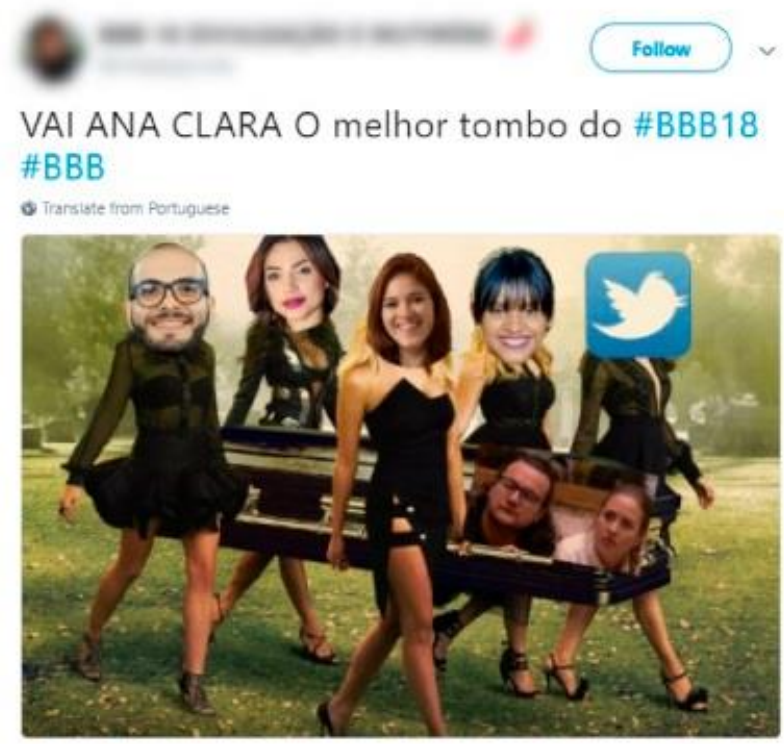

12-50 AM - 16 Feb 2019

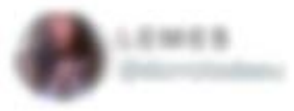

\section{Primeiro dia de velório, daqui alguns dias enterramos. \#BBB20}

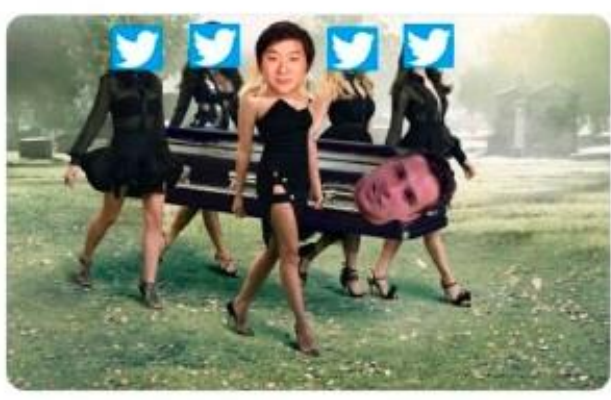

00:34, 03/02/2020. Twitter Web App 


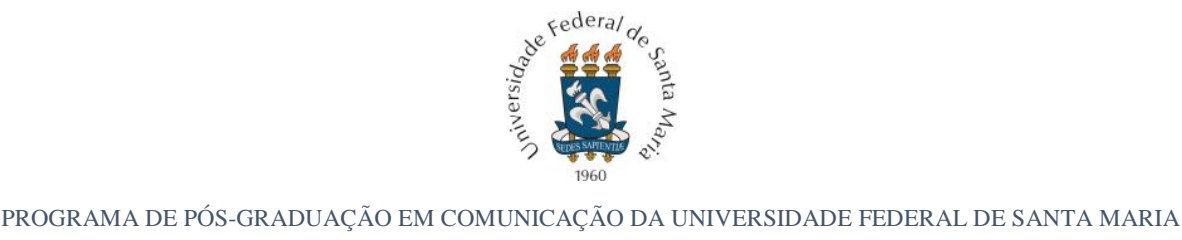

Fonte: Twitter.com

O grande meme da edição - "levanta a cabeça princesa, senão a coroa cai'- também reforça aspectos importantes do modelo particular de consumo, produção e circulação dos fandoms. A frase dita pela participante Jéssica viralizou nas redes e ganhou destaque entre os assuntos mais comentados no Twitter instantaneamente. Analisando o aspecto linguístico e estético, a maioria dos primeiros memes criados e circulados nas redes relacionavam a frase com o fato de ser segunda-feira, ou seja, uma situação externa sem qualquer afinidade com o programa ou com a participante, mas conexo ao contexto histórico. Diversas remixagens e processos de ressignificação foram criados. No exemplo a seguir (Figura 2), o usuário mescla recursos intertextuais e metalinguísticos ao trazer referências não somente do meme original com a frase e elementos indiciais que apontam as características da participante Jéssica (cabelo loiro e adereço no cabelo), mas também de um outro meme que dialoga com o emergente - o da personagem Mônica. A gama de analogia interliga o meme de maneira ainda mais densa com o contexto interpretativo. Neste caso o usuário que tiver contato com a imagem construída precisa entender e relacionar todos os elementos linguísticos, indiciais e estéticos presentes e expostos para chegar ao interpretante final. A inserção de um meme externo à realidade do programa e da emissora para expressar um sentimento relativo ao jogo provoca a ressignificação do mesmo para atender aos novos objetivos em um outro contexto e transmitindo uma mensagem distinta. 
Figura 21 - Conteúdo ressignificado do meme "Levanta a cabeça princesa, senão a coroa cai” criado por fãs.

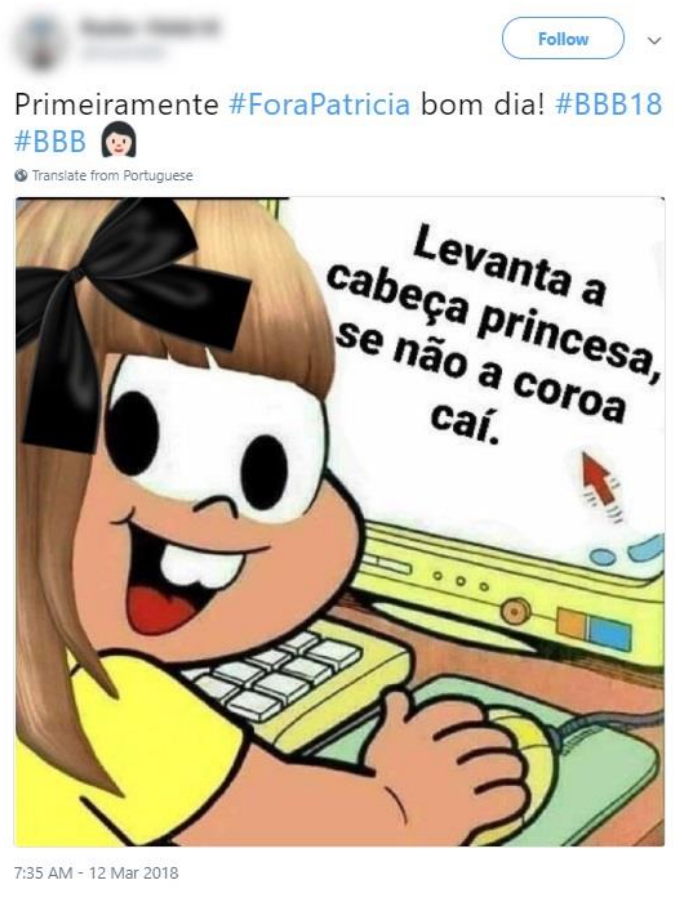

Fonte: Twitter.com

Tanto na $18^{\mathrm{a}}$ quanto na $20^{\mathrm{a}}$ edição do programa, observamos a produção e circulação de memes nas redes sociais digitais como uma prática imersa das comunidades virtuais de fãs do Big Brother Brasil. O processo de retroalimentação e ressignificação anuncia particularidades no aspecto produtivo e interpretativo da atividade fã. Em suma, é possível notar nessas produções recursos intertextuais e metalinguísticos que materializa a forma como a ação do fã é ampla, crítica e complexa. Elementos narrativos e estilísticos são articulados e inter-relacionados a fim de transmitir uma mensagem, sentimento ou valor dos usuários naquele momento. A produção e consumo de memes compreendem processos cognitivos, estéticos e linguísticos, e práticas de significação e ressignificação de mensagens criticamente.

A atribuição de sentido se faz em diálogo com o contexto, o repertório e as competências do intérprete a partir da identificação das intertextualidades que se torna possível através da capacidade de atribuir novas interpretações e valores de forma coletiva. Por conseguinte, o processo finaliza na aptidão do consumidor de disseminar a informação com base em sua interpretação final. Dessa forma, a dimensão da linguagem e o contexto de um meme são aspectos predominantes para a construção de sentido do mesmo. Tudo isso nos faz crer que a cultura de memes está intimamente relacionada à reconfiguração do consumo televisivo. 


\section{CONSIDERAÇÕES}

Por meio da imersão na comunidade de fãs do programa de reality show Big Brother Brasil, este artigo destacou a forma como os membros de fandoms se articulam e organizam. Os resultados da análise mostram algumas tendências na atuação dos fãs, principalmente quando observamos as mesmas práticas se repetindo nas edições seguintes.

As particularidades observadas incluem o hábito de narrar os acontecimentos do jogo incessantemente através das redes sociais utilizando as hashtags oficiais. Porém, o maior volume de comentários acerca do programa foi detectado durante o horário de exibição do reality na $\mathrm{TV}$, reforçando a utilização da social $T V$ como dinâmica de consumo ao compartilhar intensamente e em tempo real o que está sendo transmitido na primeira tela. O destaque nos assuntos mais comentados no Twitter de frases e expressões ditas no programa reforça a prática de social $T V$ e o hábito de narrar e repetir os diálogos dos participantes. $\mathrm{O}$ envolvimento e participação dos fãs é retroalimentada pelas enquetes realizadas no próprio Twitter, enquanto a disputa entre fandoms e as articulações nas votações revelam a complexidade da atividade fã. Durante a pesquisa de campo observamos a criação de estratégias, ações e dinâmicas coletivas extremamente efetivas para que os objetivos do fandom fossem alcançados. Além disso, em diferentes ocasiões, foi possível perceber um movimento de ativismo coletivo dos fãs com criação de campanhas de reinvindicação de dinâmicas ou ações propostas pelo programa que iam contra aos interesses e preferências dos usuários. A maioria delas foi prontamente atendida pelo BBB, que modificou regras e voltou atrás em alguns casos em prol do fandom.

O modelo particular e robusto de consumo, produção e circulação dos fãs relevou o ato de criar e ressignificar linguagens através da criação de memes com elementos intertextuais e metalinguísticos. Ao analisar os conteúdos que se destacaram na $18^{a}$ edição e outros que se repetiram na $20^{\mathrm{a}}$ temporada, conseguimos repensar as práticas tradicionais de produção e circulação de informação, assim como os processos de ressignificação a partir do consumo coletivo. Os casos apresentados elucidam a complexidade presente na produção, recepção e interpretação dos memes que depende fortemente do contexto e do repertório dos fãs que irão tanto criá-los quanto consumi-los. É uma atividade essencialmente coletiva, colaborativa e que potencializa o sentimento de pertencimento à comunidade no momento em que o fã consegue construir, interpretar e relacionar as diversas referências ali expostas. O 
processo de circulação e propagação, neste caso, é simples: só compartilha e remixa o usuário que distingue o sentido total da mensagem transmitida e se identifica com ela.

A reconfiguração da dinâmica de consumo a partir do modelo particular dos fandoms, pelo menos no caso do $\mathrm{BBB}$, transforma a experiência de assistir televisão em uma cultura participativa mais rica e complexa. O gênero reality show, com suas particularidades e conexão com o atual cenário televisivo, toma lugar como promotor de certas práticas de consumo, nas quais evidenciamos neste artigo. A investigação contribui para o entendimento dos processos comunicacionais contemporâneos de consumo material e simbólico dos produtos televisivos observados na produção de conteúdo gerados por fandoms. Defendemos que a reconfiguração da dinâmica de produção e circulação informacional passa pelo universo dos memes e, conhecer suas particularidades e representações, é conhecer de forma aprofundada e detalhada as novas práticas de consumo televisivo.

\section{REFERÊNCIAS}

AMARAL, A.; NATAL, G.; VIANA, L. Netnografia como aporte metodológico na pesquisa em comunicação digital. Sessões do Imaginário, Porto Alegre: Famecos/PUCRS, n. 20, p. 34-40, dez, 2008.

BLACKMORE, S. The power of memes. Scientific American, v. 283, n. 4, 2000.

CAMPANELLA, B. Aprendendo com as Dificuldades: Reflexões Sobre uma Etnografia Virtual com os Fãs de um Conteúdo Multiplataforma. In: Congresso Brasileiro de Ciências da Comunicação, 31. 2008, Natal, Anais, Natal: Intercom, 2008. Disponível em: http://www.intercom.org.br/papers/nacionais/2008/resumos/R3-2156-1.pdf. Acesso em: 07 jan. 2020.

Porto Alegre: Sulina, 2012.

Os olhos do Grande Irmão: Uma etnografia dos fãs do Big Brother Brasil.

CHAGAS, V. et al. A política dos memes e os memes da política: proposta metodológica de análise de conteúdo de memes dos debates eleitorais de 2014. Revista Intexto, Porto Alegre, UFRGS, n. 38, p. 173-196, jan./abr. 2017.

CHALHUB, S. A Metalinguagem. São Paulo: Editora Ática, 2005.

DAWKINS, R. The selfish gene. Oxford: OUP, 1976.

JENKINS, H. Invasores do Texto - Fãs e cultura participativa. Rio de Janeiro: Marsupial Editora, 2015.

JENKINS, H.; GREEN, J.; FORD, S. Cultura da Conexão - Criando Valor e Significado por Meio da Mídia Propagável. São Paulo: Aleph, 2014.

KNOBEL, M.; LANKSHEAR, C. Online memes, affinities, and cultural production. In: LANG, P. A New Literacies Sampler. 2007, p. 199 - 227. Disponível em: < 
https://www.researchgate.net/publication/283968435_Online_memes_affinities_and_cultural_producti on>. Acesso em: 20 mar. 2020.

MACHADO, A. Fim da televisão? Revista Famecos: mídia, cultura e tecnologia, São Paulo, v. 18, n. 1, p. 86-97, 2011. Disponível em:

<http://revistaseletronicas.pucrs.br/ojs/index.php/revistafamecos/article/view/8799>. Acesso em: 3 dez. 2019.

MATEUS, S. Reality-show: ascendências na hibridização de gênero. Contemporânea: Comunicação e Cultura, v. 10, n. 2, p. 374-390, 2012. Disponível em: 〈http://goo.gl/pSn5Io>. Acesso em: 7 jun. 2019.

PROULX, M; SHEPATIN, S. Social TV - How marketers can reach and engage audiences by connecting television to the web, social media, and mobile. New Jersey: John Wiley\& Sons Inc, 2012.

RECUERO, R. Memes em weblogs: proposta de uma taxonomia. Revista Famecos, Porto Alegre, n. 32, 2007.

RHEINGOLD, H. The Virtual Community: Homesteading on the Electronic Frontier. 2 ed. Cambridge, Massachusetts: MIT Press, 2000.

RONSINI, V. et al. Ativismo de fãs e disputas de sentido de gêneros nas interações da audiência de Em Família nas redes sociais. In: LOPES, M. I. V. de. Por uma teoria de fãs da ficção televisiva brasileira. Porto Alegre: Sulina, 2015.

SHIFMAN, L. Memes in digital culture. Cambridge: MIT Press, 2013

STEFANO, L. Convergência Midiática e Segunda Tela: uma análise das plataformas online do Big Brother Brasil. Monografia - Faculdade de Comunicação Social, Universidade Federal de Juiz de Fora, Juiz de Fora, 2016.

CONECTIVIDADE TV E WEB: a construção do fluxo e da dinâmica comunicacional do BBB18 a partir do engajamento dos fãs. Dissertação (mestrado). Universidade Federal de Juiz de Fora, Juiz de Fora, 2019.

STEFANO, L.; VIEIRA, S. Formatos audiovisuais no ecossistema digital conectivo: particularidades e desafios. Revista GEMInIS, São Carlos, UFSCar, v. 8, n. 3, pp.29-43, set. /dez. 2017. Disponível em: < http://www.revistageminis.ufscar.br/index.php/geminis/article/view/324/pdf>. Acesso em: 17 fev. 2018.

WIGGINS, B; BOWERS, G. Memes as genre: A structurational analysis of the memescape. New Media \& Society. Vol. 17, n.11, 2015, p. 1886-1906. 


\section{Luiza de Mello Stefano}

Doutoranda no Programa de Pós-Graduação em Comunicação da Universidade Federal Fluminense (UFF). Mestre em Comunicação pelo PPGCOM/UFJF e jornalista formada pela Universidade Federal de Juiz de Fora. Especialista em Comunicação e Marketing em Mídias Digitais.

Atualmente desenvolve sua tese sobre a apropriação da linguagem dos memes pela televisão aberta brasileira. Pesquisadora associada aos grupos de pesquisa TeleVisões (UFF) e Laboratório de Comunicação, Culturas Políticas e Economia da Colaboração - CoLAB (UFF).

\section{Soraya Maria Ferreira Vieira}

Comunicadora Social formada na Universidade Federal de Juiz de Fora (1985). Fez mestrado e doutorado na Pontifícia Universidade Católica de São Paulo PUC-SP no Programa de Pós Graduação em Comunicação e Semiótica. Fez em 2017 pós-doutoramento na PUC-SP - TIDD - Tecnologias da Inteligência e do Design Digital. Atualmente é professora associada da Universidade Federal de Juiz de Fora na Faculdade de Comunicação.

\section{@ $\odot \Theta($}

Esta obra está licenciada com uma Licença

Creative Commons Atribuição-NãoComercial-CompartilhaIgual 4.0 Internacional 